\title{
ROLE GAMES IN THE VILLAGES OF THE BALATON HILLS BETWEEN 1910 AND 1940
}

\author{
Emóke S. LACKOVITS
}

Dezső Laczkó Museum

H-8200 Veszprém, Erzsébet liget, Hungary

Play is an occupation that requires thinking, an activity promoting the child's physical and mental development. It educates children for community life. It is a manifestation of amusement, creativity and mimicry skills for the different age groups. It helps children to learn the rules of social life.

The child's independent life was realized in play; this was its own world independent of adults (KRESZ 1942: 45). However, the society of children was not uniform.

In the period 1910-1940 in the villages of the Balaton-Upland, as in all the Hungarian-speaking regions, children were separated by gender and age groups. Primarily they formed age groups. Boys and girls aged 3-4 years still often played together. Making mud pies and mud ovens of moist sand and mud was especially popular. But even by this age they had separate toys: the girls had dolls and the boys had animals made of cornstalks, musical instruments and tiny tools. In the most active stage, from 6 to 10 or possibly 12 not only did the toys used by boys and girls become more complicated and varied, so did their games using toys, games of singing and dancing, games of skill and sport, and they relived their various experiences in their games. For a girl playing alone her doll or dolls were the companions with which she relived what had been important for her in the recent past. Whenever tasks were allocated to the dolls, the child always played the role of the adult and she scolded or praised them. According to Samu VASAS "this is the most wonderful acting performance a person can be capable of... This play-like monologue for selfentertainment also contains, at least in embryonic form, the child's developing personality..." (VASAS 1993: 67).

However, in most cases children do not play alone. Children of the same or almost the same age always sought and found each other's company. This gave them excellent opportunities to develop play and shape different roles. Naturally, this applied mainly to those living in the same part of a village so that it was the children of families on close to the same level in village society of the past who played together. These games were occasions for collective, communal play, making them the most varied and colourful group of role games. The different occasions always provided the possibility to shape different roles. In these roles the children expressed their desires, their ideas and opinions of the world of adults. At the same time, the 
children's powers of observation and accumulated knowledge were also reflected in these games. They were familiar with many things in the world of adults, partly through training for work and by carrying out the tasks set for them, and partly from participation in the festive occasions. Whether everyday or festive occasions they were all opportunities for growing children to gather and store experiences. In her research on the subject, Klára GAZDA found that children observing the world of adults stored many things in their minds (GAZDA 1980: 109). The role games were not merely and not really only games. The children's knowledge and experiences were expressed in them. These role games contributed greatly to learning the rules of co-existence of adulthood and the village community, the laws of the society of the day.

The world of adults hid great secrets for children in many areas, such as marriage and childbirth. In their games they tried to share their thoughts to unravel these secrets. For the most part these attempts were not really successful. However, even if they did not actually discover the real essence, in external appearances they came closer to these big milestones in human life which gave them special pleasure. This is confirmed by the recollections of many elderly persons. As one of my elderly informants in Csopak says, "We played what we saw". On the whole it can be said that the games covered everything that seized their minds and feelings. The essence of these role games was imitation. They covered four major areas: work and everyday life, the milestones in human life, the world of school, and entertainment and festive days.

Imitating work and everyday life offered extremely rich opportunities for play. As children were able to observe in reality and experience in the family, the role and work of the genders were separated in play, too. They allocated these roles among themselves in keeping with the world of adults. The boys kept for themselves the representation in play of the most important work performed in the peasant economy, as they were able to observe in real life. The girls were always secondary actors in these roles. But when aspects of family life were represented in their games, the girls were given the leading role. On these occasions they played the harvest, when the boys cut the grass and the girls used pieces of thread to tie the sheaves. The boys loaded these on carts made by themselves and then piled them into small stacks. Oxen made of cornstalks were hitched to the carts made of wood or cornstalks and driven, but the children pulled the carts. In another version of the same game they used larger carts able to hold small children, sometimes made by the cildren themselves. These were loaded with handfuls of straw or rye stalks gathered after the harvest, tied together like sheaves, and held down with rods, in reality tied with threads. In this case the boys acted as horses. Two boys stood beside the shaft and a third, acting as the farmer, drove them. They pawed the earth, neighed and reared the way horses do. This horse game, in which children acted as horses, was already known in the region in the 18th century. The rules of the Lutheran Church dating from 1795 forbade this kind of game, to no avail. "Since the students are not foals and horses, but intelligent human creatures guided not with a bridle but with wisdom, the riding game is forbidden. Any child who plays this game shall be caned and 
his name inscribed in the black book." (György HRABOVSZKY 1795: 85-93). Similar role games can be encountered in the poetic autobiography of László NAGY: "Taking the toy bit between my teeth I was even proud to be able to pull my playmates with the strength of my mouth. Horses should be spirited." (NAGY 1979: 25). Children harnessed with string as a horse can also be seen on 17th-18th century painted Dutch tiles (GUNDA 1980/2: 284). Obviously, the representation by children of horses in role games was neither a new nor an exclusively Hungarian phenomenon.

While the boys played the leading role in the children's game of harvesting and carting home the harvest, the girls played the roles of their mothers in these two major work processes: they prepared lunch for the harvesters and carters. Moreover, it was always the girls who cooked, baked bread, washed, nursed infants, raised and disciplined children, represented by rag dolls. They did everything, behaved and spoke the way they saw and heard in the family.

Of course, not all the work that children could see in the space of a single year was included in their games. They ranked this work among themselves and it was generally the operations ranked as the most prestigious that were included. Besides the work processes already mentioned, behaviour at the fair and making deals were also included. They improvised imaginative dialogues between the seller and buyer. The game provided an excellent opportunity to display individual speech skills and quick reactions. The most skilful, inventive and quick-thinking boys were the actors in this popular game, in particular only boys who had already been to a fair in the company of an adult family member, driving an animal.

Some of the role games required a certain knowledge of material. One such game was the house-building brigade. The stones used for the wall of the house were made of mud. They had to be shaped in such a way that they could really create a wall when placed one on the other. For this the children had to discover laws of statics and strength of materials (VASAS 1993: 69).

In representing different stations of everyday life they also acted the parts of some of the leaders of the village community. Here too, they had priorities. As a result, only a few persons judged as outstanding were presented. One of these was the village drummer whose part was taken by a boy who spoke fluently. With an old saucepan hung around his neck and wielding two sticks he made a great noise to call the attention of the other children acting the part of the village people to the proclamation. He walked up and down the yard several times, stopping in places to read the text of the announcement, the way they saw and heard the real village drummer in reality. In the case of the girls, the one regarded as the most skilful and determined played the part of the mysterious midwife, although none of them really knew what her role was.

Another major and particularly rich area of role games was linked to the milestones in human life. One of the games was childbirth, although the informants said that they did not know how it happened. Girls took part in it and all they knew was the end result, a new life. The rest of the game showed more certainty. The girl playing the part of the mother wrapped the baby in swaddling clothes, rocked and 
fed it. The others, as they must have observed in reality, helped her. This group of games consisted of several parts. The nest stage was the christening and the blessing that followed. The boys appeared here and were also given a role. Together they played the part of the parents, grandparents and godparents. They celebrated and made merry, just as in the families.

The liveliest game was the wedding. This was limited to two elements: the wedding procession and the feast. A large number of actors were involved: bride, groom, the couple's parents, bridesmaids, groomsmen, witnesses and the guests at the wedding. They put a veil on the bride's head and the groom was given a bouquet. They took the game so seriously that it was not unusual for the adults watching them generally the grandmothers - to become involved. On one occasion in Pécsely, the grandmother of one of the girls even made the traditional almond cake served at weddings. This gave the game a quite realistic air.

Children were able to watch weddings from a very early age, either as guests with their parents, or as uninvited observers with the other children. They made a precise note of the different elements, picking out those they judged to be most important and interesting, namely the wedding procession along the street, the rich feast and the dancing. Although it was one of their favourite games, it was not played often since it required careful preparation and organization.

The enactment of funerals was also part of this group of games. The elements that drew their attention were the removal of the deceased, the funeral procession, the burial and the wake. They buried a box, sometimes containing an insect, in a corner of the yard or garden. Then they ate and drank at the wake, the way they saw in the family and among the relatives. Although death was just as natural as birth for village children, this was not a popular game. It was only played rarely since it evoked sorrow. Even so, they did not abandon it, as in reality this, too, was part of life.

School life and school roles were presented for the sake of a single actor, the teacher. This game was played often: the children vied for the role of teacher but it could only be taken by the most skilful. They, too, played it in turns. In places where the village teacher was a man, only boys could play the role. But where the teacher was a woman, girls could also play a part in the game. When they played at school, the game comprised the same things as in the real school. The behaviour and knowledge they displayed was the same as in reality. In the role of teacher they imitated what they saw and heard from the real teacher.

The representation in play of feasts and occasions of amusement was more colourful. Here, too, the games revealed what the children regard as important and interesting. One such occasion was the Sunday church service which was included in the games for the role of the minister. The person and activity of the priest was the role that all children especially longed to play, whether they admitted it or not. Real longing was also expressed in the desire to play this role. All other roles and activities were accessible for these children. They themselves were aware of this. But the minister was a chosen person. Not everyone had the possibility of reaching this status. Already as children they knew this. Not everyone was suited for the role of 
the priest in the game either. The child had to be able to speak well, be a good singer and also be outstanding at the religious instruction classes. The role could only go to such a child. Sometimes one child played it, sometimes another. The child playing the priest spread a man's blue apron over his shoulders. He stood on a stump which served as a pulpit. The congregation, that is, the other children, said what was most strongly engraved in their memories, admonitions. They also sang a lot on such occasions. The most popular role was that of the priest. Quite a few children prepared in secret for that vocation. Examples of the "priest game" and playing the role of priest are known from other Hungarian-speaking regions, too. In Holland a study was recently made of the attention children pay to the person and activity of the minister, the place he occupies in their games and the extent to which he encourages them in youth to choose this vocation. (Personal communication from Sándor GöNCZŐ, Calvinist minister.)

The customs of feast days did not have a place in the role games. Children had a real place in the practice of customs. In keeping with their age they were gradually involved in the practice of customs, becoming active participants. As a result, these fell outside their attention in their games. However, they were very interested in the church feast, although in its profane part, not the parts associated with the church or the pilgrimage. The church fair was the focus of their attention. A few children played the role of stallholders and the rest were buyers. The goods offered for sale consisted of fruit, while honeyed water served as mead. They made money from pieces of paper to be used in payment for the goods. They bought in play the kinds of things they received from the adults on such occasions: a few sweets, honey-cake and mead.

A few villages in the Balaton-Upland where the process of embourgeoisement was more advanced had their own dramatic circle and chorus. The plays presented by these circles which the children were allowed to see especially stirred their imaginations. These occasions were also included in their games. They played acting and the performers had to be able to hold the attention of the audience, that is, of the other children. They had to be able to entertain them by making the play an enjoyable experience. Only children who had the necessary ability and whose acting was accepted and enjoyed by the others undertook to play these roles. There was an opportunity here for improvisation, for creating comic situations and presenting different characters and types. Naturally, besides the individual thoughts, their main guide was what they had seen. This provided the frame and model for the game.

Only those aspects of everyday life and feasts which exercised the greatest influence on children and most stirred their imagination appeared in their games. Factors influencing this were the spectacular nature of the real event and the large number of participants. The resulting picture seen in the games is like a mosaic and does not cover the whole of life. Nevertheless, these games of imitation served as schools for learning adult life and work. They learned certain kinds of work and behaviour forms in a playful way, through games. At the same time, these role games provided ample scope for improvisation, play-acting and the unfolding of individual imagination and creativity. They also helped to shape the personality. The creation of roles, 
improvisations and variety of dialogue were generally more colorful and varied in the boys' role games than in those of the girls. In these games the children got to know the world around them and also came into direct contact with nature. The games served to prepare them for life. Reality appeared in them, even if in a childlike way.

\section{LITERATURE}

GAZDA, Klára

1980: Gyermekvilág Esztelneken (The world of children in Esztelnek) Bucharest.

GUNDA, Béla

1980: A hamburgi Altona-múzeum gyermekjáték kiállítása. (The exhibition of children's games at the Altona Museum in Hamburg). Ethnographia, 283-285.

HRABOVSZKY, György

1795: A Kis Somlyói Ev. Ecclésia 1783-1903. Iskolai törvények. (Kis Somlyó Lutheran Church 1783-1903. School rules).

KRESZ, Mária

1942: Gyermekélet és játék Sárpilisen. (Life and games of children in Sárpilis) In: Tanulmányok egy sárközi falu társadalmáról. (Studies on the society of a Sárköz village) Ed.: MÁDY, Zoltán. Budapest, 45-63.

NAGY, László

1979: Adok néktek aranyvesszőt. (I give you a golden bough) Budapest.

VASAS, Samu

1993: A kalotaszegi gyermek. A személyiségfejlődés népi hagyományai Kalotaszegen. (The child in Kalotaszeg. Folk traditions of personality development in Kalotaszeg) Cluj. 